\title{
HAK CIPTA SEBAGAI OBYEK JAMINAN FIDUSIA DITINJAU DARI UNDANG-UNDANG NOMOR 28 TAHUN 2014 TENTANG HAK CIPTA DAN UNDANG-UNDANG NOMOR 42 TAHUN 1999 TENTANG JAMINAN FIDUSIA
}

Ovia Merista

email: oviems@gmail.com

\begin{abstract}
This article shall discuss the possibility to utilize copyright as fiduciary security to a loan, in accordance to Law No. 42 of 1999 regarding fiduciary pledge/security and the Copyrights Law (Law No. 28 of 2014). The use of copyrights as a fiduciary security is made possible as copyright owner possess exclusive economic rights and not only moral rights. The procedure to be followed is regulated by Law No. 42 of 1999. The economic value of the copyright, is however, determined by the (potential) utilization of the object. In fact the value is calculated against the copyright holder's right to remuneration or royalty.
\end{abstract}

Keywords: copyrights, security to a loan, fiduciary, moral and economic exclusive rights

\begin{abstract}
Abstrak
Tulisan ini akan membahas hak cipta sebagai obyek jaminan fidusia ditinjau dari Undang-Undang Nomor 42 Tahun 1999 Tentang Jaminan Fidusia dan Undang-Undang Nomor 28 Tahun 2014 Tentang Hak Cipta. Hasil kajian menunjukkan bahwa hak cipta dapat menjadi obyek jaminan fidusia karena adanya hak ekslusif, yaitu hak ekonomi (di samping hak moral) yang dimiliki pemilik hak cipta. Penjaminan secara fidusia dari hak cipta akan mengikuti tata cara yang telah diatur oleh Undang-Undang Nomor 42 Tahun 1999. Namun nilai ekonomis dari hak cipta akan ditentukan dari pemanfaatan hak ekonomi dari obyek ciptaannya berupa jumlah imbalan atau royalti yang diterima oleh pemegang hak cipta.
\end{abstract}

Kata Kunci:

hak cipta, jaminan fidusia, Obyek jaminan fidusia, nilai ekonomis, nilai ekonomis dari hak cipta

\section{Pengantar}

Pembangunan ekonomi nasional merupakan salah satu upaya dalam mencapai masyarakat yang adil dan makmur berdasarkan Pancasila dan UUD 1945. Hal ini dapat dilakukan dengan memelihara dan meneruskan pembangunan yang berkesinambungan. Kesinambungan tersebut dapat dilihat dari terjalinnya hubungan kerjasama yang baik antara para pelaku pembangunan, baik pemerintah maupun masyarakat, perseorangan maupun badan hukum. Selain perlunya kerjasama yang baik, para pelaku pembangunan tentunya memerlukan 
dana yang cukup besar, di mana pendanaan ini diperlukan untuk memenuhi kebutuhan dalam meningkatnya kegiatan pembangunan. Para pelaku pembangunan ini akan melakukan kegiatan pinjam-meminjam untuk merealisasikan pendanaan ini.

Di Indonesia, lembaga keuangan adalah mitra usaha bagi para pelaku usaha untuk melakukan pinjam-meminjam (perkreditan). Lembaga keuangan yang memberikan kredit kepada pelaku usaha, dalam hal ini lembaga keuangan bank ataupun lembaga keuangan non bank tentunya memerlukan jaminan agar pelaku usaha tetap mempunyai tanggung jawab terhadap kredit yang diberikan. Jaminan dapat berupa benda tidak bergerak seperti tanah, di mana jaminan yang dipakai yaitu hak tanggungan. Hak tanggungan sebagaimana telah diatur dalam UndangUndang Nomor 4 Tahun 1996 tentang Hak Tanggungan yang merupakan pelaksanaan dari pasal 51, Undang-Undang Nomor 5 Tahun1960 tentang UndangUndang Pokok Agraria, dan sekaligus sebagai pengganti dari lembaga Hipotek atas tanah dan credietverband. Selain itu, hak jaminan lainnya yang sekarang ini banyak digunakan adalah Gadai, Hipotek selain tanah, dan Jaminan Fidusia. ${ }^{1}$

Gadai merupakan suatu hak kebendaan yang bersifat assessoir yang diberikan oleh pihak pemberi gadai (debitur) kepada pemegang gadai (kreditur) sebagai jaminan atas pembayaran utang. Caranya adalah dengan menyerahkan benda obyek gadai yang dapat berupa benda bergerak, bertubuh maupun tidak bertubuh ke dalam kekuasaan pemegang gadai (kreditur) atau ke dalam kekuasaan seorang pihak ketiga yang disetujui oleh kedua belah pihak. ${ }^{2}$ Hipotek adalah suatu hak kebendaan (zakelijkrecht) yang merupakan perjanjian assesoir dari suatu perjanjian pokok yang menimbulkan utang, merupakan jaminan utang, dan berobyekan benda tidak bergerak yang tidak diserahkan penguasaan atas benda tersebut ke dalam kekuasaan kreditur. Kepada pemegang hipotek diberikan

\footnotetext{
1 Undang-Undang R.I., No. 42 Tahun 1999, Jaminan Fidusia, L.N.R.I Tahun 1999 No. 168, Penjelasan Umum.

2 Munir Fuady, Hukum Jaminan Utang, Erlangga, Jakarta, 2013, hlm., 152.
} 
hak preferensi untuk didahulukan pembayarannya dari kreditur lainnya. ${ }^{3}$ Selain adanya gadai dan hipotek, terdapat jaminan fidusia yang seringkali digunakan oleh kreditur dan debitur dalam pemberian kredit.

Jaminan fidusia ini lahir untuk melengkapi kelemahan dari adanya jaminan gadai. ${ }^{4}$ Kelemahan dari gadai terlihat pada obyek jaminannya yang berada di tangan pemegang gadai. Apabila obyek tersebut diserahkan kepada penerima gadai, pemberi gadai tidak dapat menggunakan obyek tersebut padahal obyek tersebut sangat penting dan berguna bagi pemberi gadai dalam menjalankan usahanya. Jaminan Fidusia yaitu suatu jaminan utang yang bersifat kebendaan (baik utang yang telah ada maupun yang akan ada), yang pada prinsipnya memberikan barang bergerak sebagai jaminannya (tetapi dapat juga diperluas terhadap barang-barang tidak bergerak) dengan memberikan penguasaan dan penikmatan atas benda obyek jaminan utang tersebut kepada debitur (dengan jalan pengalihan hak milik atas benda obyek jaminan tersebut kepada kreditur) kemudian pihak kreditur menyerahkan kembali penguasaan dan penikmatan atas benda tersebut kepada debiturnya secara kepercayaan (fiduciary). ${ }^{5}$

Jaminan fidusia ini telah digunakan di Indonesia sejak zaman penjajahan Belanda sebagai suatu bentuk jaminan yang lahir dari yurisprudensi. Bentuk jaminan ini digunakan secara luas dalam transaksi perkreditan karena proses pembebanannya dianggap sederhana, mudah dan cepat. Sebagai jaminan kebendaan, di mana dalam praktik perbankan, fidusia sangat digemari dan populer karena dapat memenuhi kebutuhan masyarakat. 6 Fidusia dapat memberikan manfaat ganda, di mana pihak debitur masih dapat menguasai barang jaminan untuk keperluan usahanya sehari-hari dan pihak kreditur lebih praktis mempergunakan prosedur peningkatan fidusia, serta bank tidak perlu

\footnotetext{
${ }^{3}$ Id, hlm. 164.

${ }^{4}$ Sri Soedewi Mascjhun Sofwan, Beberapa Masalah Pelaksanaan Lembaga Jaminan Fidusia Di Dalam Praktik dan Perkembangan di Indonesia, Fakultas Hukum UGM, Yogyakarta, 1980, hlm., 15.

${ }^{5}$ Id, hlm. 102.

6 Tan Kamello, Hukum Jaminan Fidusia, PT. Alumni, Bandung, 2014, hlm., 13.
} 
menyediakan tempat khusus untuk penyimpanan barang jaminan seperti pada lembaga gadai. ${ }^{7}$

Pada awalnya, benda yang menjadi obyek fidusia hanya terbatas pada kekayaan benda bergerak yang berwujud dalam bentuk benda-benda dalam persediaan (inventory), benda dagangan, piutang, peralatan mesin dan kendaraan bermotor. Namun dengan menyadari makin berkembangnya kebutuhan dunia usaha serta perlunya kepastian hukum bagi pihak kreditur yang memberikan pinjaman, maka melalui Undang-Undang Jaminan Fidusia ini Pemerintah Indonesia mencoba merangkum seluruh kebutuhan akan jaminan yang tidak termasuk dan telah diatur dalam hukum positif (sebelum berlakunya Undang Undang Jaminan Fidusia) ke dalam Undang-Undang Jaminan Fidusia yaitu Undang-Undang Nomor 42 Tahun 1999 tentang Jaminan Fidusia (Undang-Undang Jaminan Fidusia).

Dalam Undang-Undang Jaminan Fidusia, obyek jaminan fidusia diberikan pengertian yang sangat luas yang meliputi tidak hanya benda bergerak yang berwujud maupun tidak berwujud, melainkan juga benda tidak bergerak yang tidak dapat dibebani dengan hak tanggungan. ${ }^{8}$ Secara langsung, undang-undang ini memberikan kesempatan kepada setiap pelaku usaha untuk dapat melakukan kredit dengan menjaminkan benda yang dimiliki walaupun benda tersebut tidak berwujud seperti hak kekayaan intelektual. Keistimewaan dari Fidusia sama halnya dengan hak kebendaan lainnya yaitu penerima fidusia (kreditur) diberikan kedudukan yang diutamakan dibandingkan kreditur lainnya.

Pembangunan ekonomi nasional dapat dihubungkan dan berkaitan erat dengan melakukan perlindungan hak kekayaan intelektual (HKI). Hal ini dapat dilihat pada Negara maju, misalnya banyak Negara mendapatkan keuntungan ekonomi dalam jumlah yang besar dari produk-produk HKI. ${ }^{9}$ Keuntungan

\footnotetext{
${ }^{7}$ Supra no. 4, pada 75.

8 Undang Undang R.I., No. 42 Tahun 1999, Jaminan Fidusia, L.N.R.I Tahun 1999 No. 168, Pasal 1 ayat (2).

${ }^{9}$ Lihat, Utomo Suryo Tomi, Hak Kekayaan Intelektual di Era Global, Graha Ilmu, Yogyakarta, 2010, hlm., 41.
} 
ekonomi tersebut dikarenakan HKI dapat dijual, dilisensikan, serta digunakan sebagai obyek jaminan utang. Telah terbukti bahwa dengan menggunakan asetaset HKI untuk dikomersialkan atau dijadikan jaminan utang, merupakan hal yang utama dan penting bagi pertumbuhan ekonomi. ${ }^{10}$

Hak kekayaan Intelektual (HKI) adalah padanan kata yang bisa digunakan untuk Intellectual Property Rights (IPR), yakni hak yang timbul dari hasil olah pikir yang menghasilkan suatu produk atau proses yang berguna untuk manusia. Pada intinya HKI adalah hak untuk menikmati secara ekonomis hasil dari suatu kreativitas intelektual. Obyek yang diatur dalam HKI adalah karya-karya yang timbul atau lahir karena kemampuan intelektual manusia. ${ }^{11}$ Secara Konvensional HKI dibagi dua, yaitu Hak Cipta dan Hak Kekayaan Industri yang terbagi atas berbagai bidang HKI, seperti paten, merek, desain, industri dan lainnya. Hak cipta merupakan perlindungan yang diberikan kepada hasil ciptaannya dan penciptanya, bukan hanya sekedar sebagai hasil penghormatan dan penghargaan terhadap hasil karya cipta seseorang saja di bidang ilmu pengetahuan, seni dan sastra, tetapi juga diharapkan akan dapat mengakibatkan semangat dan minat yang lebih besar untuk melahirkan ciptaan baru di bidang ilmu pengetahuan, seni dan sastra. ${ }^{12}$

Menurut Pasal 1 ayat 1 Undang Undang Nomor 28 Tahun 2014 Tentang Hak Cipta, "Hak Cipta adalah hak eksklusif pencipta yang timbul secara otomatis berdasarkan prinsip deklaratif setelah suatu ciptaan diwujudkan dalam bentuk nyata tanpa mengurangi pembatasan sesuai dengan ketentuan peraturan perundang-undangan." Di dalam hak ekslusif dari pemilik atau pemegang hak cipta, terdapat hak untuk memberikan ijin atau lisensi bagi pihak ketiga, Pengguna (Users) Komersial untuk dapat ikut menggunakan, mengumumkan, atau

10 World Bank, Global Economic Prospects And The Developing Countries 129 http://siteresources.worldbank.org/INTGEP2002/Resources/gep2002complete.pdf, 25/11/15

11 Direktorat Jendral Hak Kekayaan Intelektual Kementerian Hukum Dan Hak Asasi Manusia R.I., Buku Panduan Hak Kekayaan Intelektual iii, Tanggerang, 2013.

12 Rachmadi Usman, Hukum Hak Atas Kekayaan Intelektual: Perlindungan dan Dimensi Hukumnya di Indonesia, Alumni, Bandung, 2003, hlm., 56. 
memperbanyak karya cipta yang dilindungi hak cipta. Pemberian ijin atau lisensi dari pemilik atau pemegang hak cipta kepada users pada umumnya disertai kompensasi yang harus dibayar oleh pengguna komersial atau pemegang hak cipta. Kompensasi yang harus dibayarkan tersebut dinamakan Royalti.

Hak cipta yang merupakan hak ekslusif tersebut terdiri atas hak ekonomi (economic rights). Hak ekonomi yaitu hak untuk mendapatkan manfaat ekonomi atas ciptaan serta produk hak terkait. Manfaat ekonomi tersebut akan didapat saat pemegang hak cipta tersebut memberikan lisensi kepada pihak ketiga untuk menggunakan, mengumumkan, atau memperbanyak karya ciptanya dengan mendapatkan royalti. Selain hak ekonomi, hak cipta mempunyai hak moral yaitu hak yang melekat pada diri pencipta atau pelaku yang tidak dapat dihilangkan atau dihapus tanpa alasan apapun, walaupun hak cipta atau hak terkait telah dialihkan. Berkaitan dengan hak ekonomi yang memberikan keuntungan secara finansial pada hak cipta, maka dapat dikatakan bahwa hak cipta dapat menjadi obyek jaminan.

Karakteristik suatu benda yang digunakan sebagai obyek jaminan utang adalah benda yang mempunyai nilai ekonomis dalam artian suatu saat apabila debitur tidak dapat melunasi utangnya, benda tersebut dapat menutup utang tersebut. Dalam kaitannya dengan hak cipta sebagai obyek jaminan, suatu hak cipta yang dapat digunakan sebagai obyek jaminan tentunya yang mempunyai nilai ekonomis, telah didaftarkan ke Direktorat Jenderal Hak Kekayaan Intelektual, dan masih dalam masa perlindungan karena berkaitan dengan nilai keekonomian hak cipta tersebut. Lembaga jaminan yang paling memungkinkan dibebankan pada hak cipta sebagai obyek jaminan utang adalah lembaga jaminan fidusia mengingat pada jenis obyek jaminan yang berupa benda bergerak dan mengenai penyerahan benda jaminan. ${ }^{13}$

\footnotetext{
${ }^{13}$ Sudjana, Hak Cipta sebagai Jaminan Kebendaan Bergerak dikaitkan dengan Pengembangan Obyek Fidusia, Jurnal Mimbar Hukum UGM, Volume 24, Nomor 3, 2012, hlm., 406-407.
} 
Pada awalnya Undang-Undang Hak Cipta tidak mengatur mengenai hak cipta sebagai obyek jaminan. Dengan dikeluarkanya undang-undang terbaru mengenai hak cipta yaitu Undang-Undang Nomor 28 Tahun 2014 Tentang Hak Cipta dalam Pasal 16 ayat 3 dinyatakan dengan tegas bahwa obyek hak cipta dapat dijadikan obyek jaminan fidusia. Di mana dalam Undang-Undang Hak Cipta ini disebutkan pula bahwa dalam pelaksanaannya hak cipta dapat dijadikan obyek fidusia dengan mengikuti tata cara yang telah diatur oleh Undang-Undang Jaminan Fidusia. Dalam hal ini hak cipta mempunyai nilai ekonomi akan tetapi karena benda tidak berwujud, hak cipta sulit untuk ditentukan nilai ekonomisnya, tidak seperti barang bergerak yang bertubuh misalnya mobil, tanah maupun perhiasan.

\section{Jaminan Fidusia Dan Pengaturannya di Indonesia}

Jaminan mempunyai fungsi yang sangat penting dalam kegiatan perekonomian. Hal ini dikarenakan dalam pemberian pinjaman modal dari lembaga keuangan (baik bank maupun bukan bank) disyaratkan adanya suatu jaminan, yang harus dipenuhi oleh debitur apabila mereka ingin mendapatkan pinjaman/tambahan modal, berupa kredit tersebut baik untuk jangka panjang maupun jangka pendek. ${ }^{14}$ Dengan begitu, jaminan akan ada apabila adanya kredit yang diberikan oleh lembaga keuangan.

Dalam hukum jaminan dikenal adanya jaminan secara umum dan secara khusus. Jaminan secara umum, yaitu jaminan yang timbul dari undang-undang, sedangkan jaminan secara khusus merupakan jaminan yang timbul dari suatu perjanjian baik berupa perjanjian kebendaan maupun perjanjian perorangan. Perjanjian-perjanjian jaminan khusus tersebut bersifar accessoir terhadap perjanjian pokoknya, artinya perjanjian ini merupakan perjanjian tambahan dari adanya perjanjian kredit. Dengan adanya jaminan umum, maka hukum jaminan telah memberikan perlindungan berupa jaminan secara umum kepada kreditur bagi pelunasan utang debitur, akan tetapi untuk memberikan rasa aman dan

\footnotetext{
14 Jatmiko Winarno, Perlindungan Hukum Bagi Kreditor Pada Perjanjian Jaminan Fidusia, Jurnal Independent Fakultas Hukum, ISSN:2338-7777, hlm., 44.
} 
kepastian hukum bagi para pihak, maka dalam praktek sering dibuat perjanjian jaminan, baik berupa perjanjian jaminan kebendaan maupun jaminan perorangan. ${ }^{15}$

Bagi pihak debitur bentuk jaminan yang baik adalah bentuk jaminan yang tidak akan melumpuhkan kegiatan usahanya sehari-hari, sedangkan bagi kreditur jaminan yang baik adalah jaminan yang dapat memberikan rasa aman dan kepastian hukum bahwa kredit yang diberikan dapat diperoleh kembali tepat pada waktunya. Saat ini, lembaga jaminan yang banyak diterapkan dalam perjanjian kredit salah satunya adalah jaminan fidusia, di mana lembaga jaminan ini digunakan apabila obyek agunannya adalah benda-benda bergerak. Fidusia yang berarti penyerahan hak milik atas dasar kepercayaan memberikan kedudukan kepada debitur untuk tetap menguasai barang jaminan, walaupun hanya sebagai peminjam untuk sementara waktu atau tidak lagi sebagai pemilik.

Lembaga fidusia ini berbeda halnya dengan gadai yang terdapat pada Pasal 1152 KUHPerdata, yang menyatakan bahwa apabila benda bergerak yang dijadikan jaminan tersebut tetap dibiarkan dikuasai debitur maka jaminan tersebut akan tidak sah. ${ }^{16}$ Dalam jaminan fidusia, barang yang dijadikan jaminan akan tetap sah walaupun barang tersebut berada di tangan debitur. Hal ini merupakan perkembangan dari jaminan gadai. Kelebihan jaminan fidusia dengan gadai adalah obyek jaminannya tetap dapat dimanfaatkan oleh debitur untuk kegiatan usahanya, dalam hal ini intinya terletak pada aspek penguasaan atas obyek jaminannya.

Jaminan Fidusia sebenarnya telah dikenal sejak zaman Romawi, dan di Negeri Belanda diakui oleh Hoge Raad mula-mula dalam Arrest tanggal 25 Januari 1929 (Briebrouwern Arrest). Pertama kali di Indonesia lembaga ini dikenal melalui Yurisprudensi tahun 1932 dalam perkara antara Bataafsche Petrolum Maatschappij melawan Pedro Clignett, di mana Hoggerechtschof (Mahkamah

\footnotetext{
15 Marulak Pardede, Implementasi Jaminan Fidusia Dalam Pemberian Kredit di Indonesia, Laporan Akhir Penelitian Hukum, BPHN, Departemen Hukum dan HAM Republik Indonesia, Jakarta, 2006, hlm., 27.

${ }^{16}$ Supra no. 14, hlm., 44.
} 
Agung pada waktu itu) menyatakan penyerahan hak milik secara fidusia atas barang-barang bergerak sebagai jaminan hutang kepada kreditur yang sah. ${ }^{17} \mathrm{Hal}$ tersebut berkembang dan dipakai sebagai jaminan para pelaku usaha.

Jaminan fidusia adalah suatu jaminan utang yang bersifat kebendaan (baik utang yang telah ada maupun utang yang akan ada), yang pada prinsipnya memberikan barang bergerak sebagai jaminannya (tetapi dapat juga diperluas terhadap barang-barang tidak bergerak) dengan memberikan penguasaan dan penikmatan atas benda obyek jaminan utang tersebut kepada debitur (dengan jalan pengalihan hak milik atas benda obyek jaminan tersebut kepada kreditur) kemudian pihak kreditur menyerahkan kembali penguasaan dan penikmatan atas benda tersebut kepada debiturnya secara kepercayaan (fiduciary). ${ }^{18}$

Pengaturan mengenai jaminan fidusia pada saat ini telah diatur dalam Undang-Undang No. 42 Tahun 1999 tentang Jaminan Fidusia. Dalam undangundang ini telah diatur ketentuan-ketentuan yang harus dipatuhi, ditaati serta dilaksanakan dalam melakukan perjanjian kredit dengan jaminan fidusia, termasuk ketentuan yang mewajibkan untuk mendaftarkan obyek jaminan fidusia di kantor pendaftaran fidusia. Pasal 1 butir 1 Undang-Undang No. 42 tahun 1999 Tentang Jaminan Fidusia menjelaskan bahwa:

"Fidusia adalah pengalihan hak kepemilikan suatu benda atas dasar kepercayaan dengan ketentuan bahwa benda yang hak kepemilikannya dialihkan tersebut tetap dalam penguasaan pemilik benda."

Pengalihan hak kepemilikan atas suatu benda akan beralih karena adanya perjanjian kredit, akan tetapi sebagai jaminan, penguasaan pemilik benda tersebut berada tetap di tangan debitur. Hal ini karena adanya suatu kepercayaan antara debitur dan kreditur. Oleh karena itu, pendaftaran obyek jaminan di kantor pendaftaran fidusia merupakan suatu hal yang penting dan wajib dilakukan oleh kreditur.

\footnotetext{
17 Supra no. 4, hlm., 73.

18 Supra no. 2, hlm., 102.
} 
Definisi atau pengertian mengenai jaminan fidusia telah diatur dalam Pasal 1 angka 2 Undang-Undang Nomor 42 Tahun 1999 yang menyatakan jaminan fidusia adalah hak jaminan atas benda bergerak baik yang berwujud maupun yang tidak berwujud dan benda bergerak yang tidak dapat dibebani hak tanggungan sebagaimana diatur dalam Undang-Undang Nomor 4 Tahun 1996 Tentang Hak Tanggungan yang tetap berada dalam penguasaan pemberi fidusia, sebagaimana agunan bagi pelunasan utang tertentu yang memberikan kedudukan yang diutamakan kepada penerima fidusia terhadap kreditur lainnya. Benda-benda sebagai obyek jaminan fidusia berdasarkan Pasal 1 ayat 4 Undang-Undang Nomor 42 Tahun 1999 tentang Jaminan Fidusia adalah :

"Benda adalah segala sesuatu yang dapat dimiliki dan dialihkan baik yang berwujud maupun tidak berwujud, yang terdaftar maupun tidak terdaftar, yang bergerak maupun yang tidak bergerak yang tidak dapat dibebani hak tanggungan atau hipotik."

Berdasarkan Pasal 504 KUHPerdata, benda dibedakan menjadi 2 (dua) yaitu benda bergerak dan benda tidak bergerak. Benda tidak bergerak diatur dalam Pasal 506-508 KUHPerdata. Sedangkan untuk benda bergerak diatur dalam Pasal 509-518 KUHPerdata. Suatu benda dapat tergolong dalam golongan benda yang tidak bergerak ("onroerend") pertama, karena sifatnya. Kedua, karena tujuan pemakaiannya, dan ketiga, karena memang demikian ditentukan oleh undang-undang. Benda yang tidak bergerak karena sifatnya ialah tanah, termasuk segala sesuatu yang secara langsung atau tidak langsung, karena perbuatan alam atau perbuatan manusia, digabungkan secara erat menjadi satu dengan tanah itu. Selanjutnya, benda tidak bergerak ialah benda karena memang demikian ditentukan oleh undang-undang, segala hak atau penagihan yang mengenai suatu benda yang tidak bergerak.

Pada sisi lain, suatu benda dihitung termasuk golongan benda yang bergerak karena sifatnya atau karena ditentukan oleh undang-undang. Suatu benda yang bergerak karena sifatnya ialah benda yang tidak tergabung dengan tanah atau dimaksudkan untuk mengikuti tanah atau bangunan, jadi 
misalnya barang perabot rumah tangga. Hal ini merupakan benda yang bergerak yang berwujud. Selain itu, terdapat benda bergerak yang tidak berwujud. Benda tidak berwujud adalah benda yang bergerak karena penetapan undangundang ialah misalnya vruchtgebruik dari suatu benda yang bergerak, lijfrenten, surat-surat sero dari suatu perseroan perdagangan, surat-surat obligasi negara, hak-hak kekayaan intelektual, seperti hak cipta, hak mereka, hak paten dan sebagainya. ${ }^{19}$

Selanjutnya, pada Pasal 3 Undang-Undang Nomor 42 Tahun 1999 tentang Jaminan Fidusia, dijelaskan bahwa undang-undang ini tidak berlaku terhadap :

a. Hak Tanggungan yang berkaitan dengan tanah dan bangunan, sepanjang peraturan perundang-undangan yang berlaku menentukan jaminan atas benda-benda tersebut wajib didaftar;

b. Hipotik atas kapal yang terdaftar dengan isi kotor berukuran $20 \mathrm{M}^{3}$ atau lebih;

c. Hipotik atas pesawat terbang; dan

d. Gadai.

Dapat disimpulkan bahwa benda jaminan fidusia adalah benda bergerak atau yang dipersamakan, sehingga maksud dalam huruf b di atas bahwa dasar ukuran $20 \mathrm{M}^{3}$ merupakan batas ukuran yang digunakan bagi yang tidak dapat difidusiakan, sedangkan terhadap huruf c lebih lanjut dijelaskan dalam up grading dan refresing course pada Konferda I.N.I. Jawa Tengah pada tanggal 12- 13 April 2003 bahwa Pesawat Terbang dapat difidusiakan tetapi terhadap mesinnya (engine) dapat diletakkan fidusia. Dalam ketentuan menyangkut benda jaminan fidusia juga ditegaskan, bangunan di atas tanah orang lain yang tidak dibebani dengan Hak Tanggungan berdasarkan Undang-Undang Nomor 4 Tahun 1996 tentang Hak Tanggungan dapat dijadikan obyek jaminan fidusia. Terhadap benda jaminan fidusia hal penting yang perlu dicermati adalah menyangkut prinsip benda fidusia haruslah merupakan benda milik pemberi fidusia dan bukan

${ }^{19}$ Subekti, Pokok-Pokok Hukum Perdata, Intermasa, Jakarta, 2005, hlm., 61-62. 
merupakan benda yang berada dalam status kepemilikan orang lain. ${ }^{20}$

Pasal 11 sampai dengan Pasal 18 Undang-Undang Nomor 42 Tahun 1999 tentang Jaminan Fidusia menentukan bahwa benda yang baik berada di dalam wilayah Negara Republik Indonesia maupun yang di luar Negara Republik Indonesia wajib didaftarkan. Ketentuan tentang adanya kewajiban pendaftaran jaminan fidusia dapat dikatakan merupakan terobosan yang penting mengingat bahwa pada umumnya obyek jaminan fidusia merupakan benda yang tidak terdaftar sehingga sulit mengetahui siapa pemiliknya. Menurut Pasal 11 UndangUndang Nomor 42 Tahun 1999 tentang Jaminan Fidusia dijelaskan bahwa perjanjian fidusia secara akta notariil saja tidaklah cukup, tetapi harus didaftarkan. Dalam hal ini pendaftaran suatu benda tersebut harus dilakukan di Kantor Pendaftaran Fidusia, yang berada dalam lingkup tugas Departemen Hukum dan HAM. ${ }^{21}$ Pendaftaran terlebih dahulu melalui Kantor Jaminan Fidusia, berguna agar suatu benda tersebut terdaftar dan barang siapa yang menguasai benda bergerak tersebut maka ia akan dianggap sebagai pemiliknya. ${ }^{22}$

\section{Pengaturan Hak Cipta Di Indonesia}

Pada mulanya hak cipta diatur menurut Auteurswet Staatsblad 1912 Nomor 600. Pada Kongres Kebudayaan Indonesia ke-2 pada bulan Oktober tahun 1951 di Bandung, penggunaan istilah hak pengarang dipersoalkan karena dipandang menyempitkan pengertian hak cipta. Di dalam Auteurswet Staatsblad 1912 Nomor 600, istilah yang dipakai Auteursrechts, disadur dari Bahasa Belanda, yang artinya hak pengarang. Istilah ini begitu sempit karena berkorelasi dengan mengarang saja, sedangkan cakupan hak cipta jauh lebih luas dari hak-hak pengarang. Kata "cipta" menyangkut daya kesanggupan batin (pikiran) untuk mengadakan sesuatu

\footnotetext{
${ }^{20}$ Supra no. 2, hlm., 49.

21 Ketut Marita Widyasari Puspita, I Gusti Ayu Puspawati dan Marwanto, Pelaksanaan Pengikatan Jaminan Fidusia Dalam Kredit Perbankan, Jurnal Hukum Bisnis Fakultas Hukum Universitas Udayana, Volume 02, Nomor 01, 2, 2014.

22 Munir Fuadi, Jaminan Fidusia, Citra Aditya Bakti, Bandung, 2000, hlm., 74.
} 
yang baru, terutama di lapangan kesenian. ${ }^{23}$ Oleh karena itu, kongres memutuskan untuk mengganti istilah yang diperkenalkan dengan istilah hak cipta. ${ }^{24}$ Istilah hak cipta ini yang kemudian dipakai dalam peraturan perundang-undangan selanjutnya pengertian kedua istilah tersebut menurut sejarah perkembangannya mempunyai perbedaan yang cukup besar. ${ }^{25}$

Istilah Copyright (Hak Cipta) pertama kali dikemukakan dalam Berne Convention yang diadakan tahun 1886 yaitu International Convention for the Protection of Literary and Artistic Work, ditandatangani di Berne, Swiss. Konvensi ini telah mengalami beberapa kali revisi, yaitu di Berlin 1908, Roma 1928, Brussel 1967, dan terakhir di Paris 1971.26 Dalam Berne Convention, pengertian Hak Cipta tidak dirumuskan dalam pasal tersendiri namun tersirat dalam Article 2, Article 3, Article 11 dan Article 13 yang isinya diserap dalam Pasal 2 jo Pasal 10 Auteurswet 1912. Dalam Auteurswet 1912 Pasal 1 diatur bahwa:

Hak Cipta adalah hak tunggal dari Pencipta atau hak dari yang mendapat hak tersebut, atas hasil Ciptaannya dalam lapangan kesusastraan, pengetahuan dan kesenian, untuk mengumumkan dan memperbanyak dengan mengingat pembatasan-pembatasan yang ditentukan oleh undang-undang.

L.J. Taylor menyatakan hak cipta melindungi suatu ekspresi dari sebuah ide, sedangkan ide yang belum diwujudkan belum dilindungi. Dari pengertian ini sangat jelas bahwa hak cipta diberikan hanya pada karya-karya yang merupakan penuangan ide secara nyata, bukan sekedar gagasan dan ide semata. ${ }^{27}$

Secara umum pembentukan peraturan perundang-undangan di bidang hak cipta di Indonesia didasarkan pada ratifikasi terhadap perjanjian-perjanjian internasional di bidang Hak Cipta, beberapa perjanjian itu adalah Konvensi Bern

23 Kamus Besar Bahasa Indonesia, Balai Pustaka, Jakarta, 1988.

24 Eddy Damian, Hak Kekayaan Intelektual: Suatu Pengantar, Alumni, Bandung, hlm., 112.

25 Muhamad Djumhana dan Djubaedillah, Hak Milik Intelektual Sejarah, Teori dan Prakteknya di Indonesia, Citra Aditya Bakti, Bandung, 1993, hlm., 47.

26 Budi Agus Riswandi, Permasalahan Pelanggaran dan Langkah Hukum Hak Cipta Atas Musik dan Lagu yang Dituangkan Dalam Bentuk VCD dan DVD, Jurnal Hukum, Volume 16, Nomor 4, 2009, hlm., 573.

27 Id, hlm. 573. 
1886 tentang Perlindungan Karya Sastra dan Seni; Konvensi Hak Cipta Universal 1955 atau Universal Copyright Convention; Konvensi Roma 1961; Konvensi Jenewa 1967; dan TRIPs 1994 (Trade Related Aspects on Intellectual Property Rights 1994). ${ }^{28} \mathrm{Hal}$ ini berarti Indonesia harus membuat atau memberlakukan agar hukum Indonesia khususnya Hak Kekayaan Intelektual sesuai dengan konvensi-konvensi yang telah diratifikasinya. Perlindungan yang diberikan oleh pemerintah kepada hasil ciptaan dan penciptanya, bukan hanya sekedar sebagai hasil penghormatan dan penghargaan terhadap hasil karya cipta seseorang saja di bidang ilmu pengetahuan, seni dan sastra, tetapi juga diharapkan akan dapat membangkitkan semangat dan minat yang lebih besar untuk melahirkan ciptaan baru di bidang ilmu pengetahuan, seni dan sastra. ${ }^{29}$

Setelah merdeka, Undang-Undang Hak Cipta pertama kali diatur dalam Undang-Undang Nomor 6 Tahun 1982 tentang Hak Cipta. Kemudian diubah dengan Undang-Undang Nomor 7 Tahun 1987. Pada tahun 1997 diubah lagi dengan Undang-Undang Nomor 12 Tahun 1997. Di tahun 2002, Undang-Undang Hak Cipta kembali mengalami perubahan dan diatur dalam Undang-Undang Nomor 19 Tahun 2002 tentang Hak Cipta, dan akhirnya pada tahun 2014 pengaturan hak cipta mengalami perubahan kembali dengan diundangkannya Undang-Undang Nomor 28 Tahun 2014 tentang Hak Cipta. Beberapa peraturan pelaksana di bidang hak cipta adalah sebagai berikut: ${ }^{30}$

1. Peraturan Pemerintah RI No. 14 Tahun 1986 Jo Peraturan Pemerintah RI No. 7 Tahun 1989 tentang Dewan Hak Cipta;

2. Peraturan Pemerintah RI No. 1 Tahun 1989 tentang Penerjemahan dan/atau Perbanyak Ciptaan untuk Kepentingan Pendidikan, Ilmu Pengetahuan, Penelitian dan Pengembangan;

3. Keputusan Presiden RI No. 17 Tahun 1988 tentang Persetujuan Mengenai Perlindungan Hukum Secara Timbal Balik Terhadap Hak Cipta atas Karya Rekaman Suara antara Negara Republik Indonesia dengan Masyarakat Eropa;

4. Keputusan Presiden RI No. 25 Tahun 1989 tentang Pengesahan

\footnotetext{
${ }^{28}$ Supra no. 24, hlm., 137.

29 Supra no. 14.

30 Supra no. 11, hlm., 3.
} 
Persetujuan Mengenai Perlindungan Hukum Secara Timbal Balik Terhadap Hak Cipta antara Republik Indonesia dengan Amerika Serikat;

5. Keputusan Presiden RI No. 38 Tahun 1993 tentang Pengesahan Pesetujuan Mengenai Perlindungan Hukum Secara Timbal Balik Terhadap Hak Cipta antara Republik Indonesia dengan Australia;

6. Keputusan Presiden RI No. 56 Tahun 1994 tentang Pengesahan Persetujuan Mengenai Perlindungan Hukum Secara Timbal Balik Terhadap Hak Cipta antara Republik Indonesia dengan Inggris;

7. Keputusan Presiden RI No. 18 Tahun 1997 tentang Pengesanan Berne Convention For The Protection of Literary andArtistic Works;

8. Keputusan Presiden RI No. 19 Tahun 1997 tentang Pengesahan WIPO Copyrights Treaty;

9. Keputusan Presiden RI No. 74 Tahun 2004 tentang Pengesahan WIPO Performances and Phonogram Treaty (WPPT);

10. Peraturan Menteri Kehakiman RI No. M.Ol-HC.03.01 Tahun 1987 tentang Pendaftaran Ciptaan;

11. Keputusan Menteri Kehakiman RI No. M.04.PW.07.03 Tahun 1988 tentang Penyidikan Hak Cipta;

12. Surat Edaran Menteri Kehakiman RI Jo.M.01.PW.07.03 Tahun 1990 tentang Kewenangan Menyidik Tindak Pidana Hak Cipta;

13. Surat Edaran Menteri Kehakiman RI No. M.02.HC.03.01 Tahun 1991 tentang kewajiban Melampirkan NPWP dalam Permohonan Pendaftaran Ciptaan dan Pencatatan Pemindahan Hak Cipta Terdaftar. ${ }^{31}$

Pengertian Hak Cipta juga dijelaskan pada Pasal 1 Undang-Undang Nomor 28 Tahun 2014 Tentang Hak Cipta, yaitu:

Hak Cipta adalah hak eksklusif pencipta yang timbul secara otomatis berdasarkan prinsip deklaratif setelah suatu ciptaan diwujudkan dalam bentuk nyata tanpa mengurangi pembatasan sesuai dengan ketentuan peraturan perundang-undangan.

Menurut Hutauruk ada dua unsur penting yang terkandung dari rumusan pengertian hak cipta yang termuat dalam ketentuan UUHC Indonesia, yaitu: ${ }^{32}$

1. Hak yang dapat dialihkan kepada pihak lain.

\footnotetext{
${ }^{31}$ Supra no. 11 , hlm., 4

32 M. Hutauruk, Peraturan Hak Cipta Nasional, Erlangga, Jakarta, 1982, hlm., 11.
} 
2. Hak moral yang dalam keadaan bagaimanapun, dan dengan jalan apa pun tidak dapat ditinggalkan daripada mengumumkan karyanya, menetapkan judulnya, mencantumkan nama sebenarnya atau nama samarannya dan mempertahankan keutuhan atau integritas ceritanya.

Hak yang dapat dipindahkan atau dialihkan itu sekaligus merupakan bukti nyata bahwa hak cipta itu merupakan hak kebendaan. Melalui definisi hak cipta tersebut pula dapat diketahui bahwa hak cipta yang merupakan bagian dari Hak Kekayaan Intelektual merupakan satu bagian dari benda tidak berwujud (benda Immaterial). ${ }^{33}$

Hak cipta merupakan salah satu bagian dari kekayaan intelektual yang memiliki ruang lingkup obyek dilindungi paling luas, karena mencakup ilmu pengetahuan, seni, dan sastra (art literary) yang didalamnya mencakup pula program komputer. Perkembangan ekonomi kreatif yang menjadi salah satu andalan Indonesia dan berbagai negara dan berkembangan pesatnya teknologi informasi dan komunikasi mengharuskan adanya pembaruan undang-undang Hak Cipta, oleh sebab itulah selanjutnya pemerintah membentuk Undang-Undang Hak Cipta Nomor 28 Tahun 2014 tentang Hak Cipta yang memenuhi unsur perlindungan dan pengembangan ekonomi kreatif, selanjutnya maka diharapkan kontribusi sektor hak cipta dan hak terkait bagi perekonomian negara dapat lebih optimal. ${ }^{34}$

Indonesia merupakan Negara yang memiliki keanekaragaman etnik/suku bangsa, budaya dan agama serta kekayaan yang melimpah di bidang ilmu pengetahuan, seni dana sastra berikut pengembangan-pengembangannya. Sebagai potensi nasional semua itu memerlukan adanya perlindungan yang memadai terhadap kekayaan intelektual khususnya ciptaan yang lahir dari keanekaragaman

33 Arif Lutfiansori, Hak Cipta dan Perlindungan Folklor di Indonesia, Graha Ilmu, Yogyakarta, 2010, hlm., 69.

34 Undang-Undang R.I., No. 28 Tahun 2014, Hak Cipta, L.N.R.I Tahun 2014 No. 266, Penjelasan umum. 
dan kekayaan tersebut. ${ }^{35}$ Perkembangan di bidang teknologi perekaman, telekomunikasi dan informasi digital yang demikian pesat dalam beberapa dasawarsa terakhir, telah menuntut adanya peningkatan perlindungan yang memadai baik bagi pencipta maupun pemilik hak terkait dengan tetap memperhatikan kepentingan masyarakat luas. Apabila tuntutan tersebut ditangani secara serius termasuk diantaranya dengan menyediakan sistem pengaturan yang baik, sendi-sendi kehidupan dan perekonomian Indonesia akan meningkat, dan kredibilitas citra bangsa yang baik akan tetap terjaga didunia internasional. 36

Pengesahan Undang-Undang Nomor 28 tahun 2014 tentang Hak Cipta upaya pemerintah untuk melindungi hak ekonomi dan hak moral pencipta dan pihak terkait lainnya. Undang-Undang Hak Cipta yang baru ini juga memiliki semangat untuk mendukung seluruh pencipta dan para pelaku usaha untuk semakin kreatif melahirkan karyanya. Setelah disahkannya Rancangan UndangUndang Hak Cipta pada tanggal 15 September 2014 lalu maka Undang-Undang Hak Cipta yang memenuhi unsur pelindungan dan pengembangan ekonomi kreatif ini diharapkan berkontribusi pada sektor hak cipta dan hak bagi perekonomian negara dapat lebih optimal. ${ }^{37}$

Di dalam Undang-Undang Nomor 28 tahun 2014 tentang Hak Cipta dijelaskan bahwa Hak Cipta sebagaimana dimaksud dalam Pasal 3 huruf a merupakan hak eksklusif yang terdiri atas hak moral dan hak ekonomi. Hak eksklusif adalah hak yang hanya diperuntukkan bagi Pencipta, sehingga tidak ada pihak lain yang dapat memanfaatkan hak tersebut tanpa izin Pencipta. Definisi mengenai hak ekslusif tersebut di atas dapat disimpulkan bahwa hak cipta adalah

\footnotetext{
35 KemenkumHAM, Pembahasan RUU tentang Hak Cipta, http://www.djpp.kemenkumham.go.id/ pembahasan-ruu/64-rancangan-undang-undang/2112-rancangan-undang-undang-tentang-hakcipta.html, 17 November 2015. 36 Id.

37 Sosialisasi Undang-undang No.28 Tahun 2014 tentang Hak Cipta di Kampus UGM, Undangundang Hak Cipta terbaru Terhadap Iklim Hukum Bisnis Di Indonesia, http://lppm.ugm.ac.id/2014/11/sosialisasi-uu-no-28-tahun-2014-tentang-hak-cipta-dikampusugm/, 19 November 2015.
} 
hak kebendaan yang bersifat eksklusif bagi seorang pencipta atau penerima hak atas suatu karya atau ciptaannya di bidang ilmu pengetahuan, seni, dan sastra. ${ }^{38}$ Hak moral yang terdapat pada hak cipta melekat secara abadi pada diri Pencipta. Hak tersebut untuk tetap mencantumkan atau tidak mencantumkan namanya pada salinan sehubungan dengan pemakaian ciptaannya untuk umum; menggunakan nama aliasnya atau samarannya; mengubah ciptaannya sesuai dengan kepatutan dalam masyarakat; mengubah judul dan anak judul ciptaan; dan mempertahankan haknya dalam hal terjadi distorsi ciptaan, mutilasi ciptaan, modifikasi ciptaan, atau hal yang bersifat merugikan kehormatan diri atau reputasinya. 39

Sebagai suatu hak kebendaan yang bersifat khusus, hak cipta memiliki sifat dan karakter yang sedikit berbeda dengan hak kebendaan pada umumnya. hak ekonomi atas suatu ciptaan tetap berada di tangan pencipta atau pemegang hak cipta selama pencipta atau pemegang hak cipta tidak mengalihkan seluruh hak ekonomi dari pencipta atau pemegang hak cipta tersebut kepada penerima pengalihan hak atas ciptaan. Pemegang hak cipta yang bukan pencipta hanya memiliki sebagian dari hak eksklusif berupa hak ekonomi. Pencipta atau pemegang hak cipta memiliki hak ekonomi untuk melakukan: penerbitan ciptaan; penggandaan ciptaan dalam segala bentuknya; penerjemahan ciptaan; pengadaptasian, pengaransemenan, atau pentransformasian ciptaan; pendistribusian ciptaan atau salinannya; pertunjukan ciptaan; pengumuman ciptaan; komunikasi ciptaan; dan penyewaan ciptaan. ${ }^{40}$ Setiap orang yang melaksanakan hak ekonomi dalam hal kegiatan-kegiatan tersebut wajib mendapatkan izin pencipta atau pemegang hak cipta.

Hak kebendaan pada hak cipta memberikan konsekuensi bahwa hak cipta dapat dialihkan. Pengalihan tersebut bukan hak moral dari suatu ciptaan tetap hak ekonomi yang dapat dialihkan. Hak cipta dapat beralih atau dialihkan, baik

\footnotetext{
38 OK. Saidin, Aspek Hukum Hak Kekayaan Intelektual (Intellectual Property Rights), Rajawali Pers, Jakarta, 2010, hlm., 58.

39 Undang Undang R.I., No.28 Tahun 2014, Hak Cipta, L.N.R.I Tahun 2014 No. 266, Pasal 4.

40 Undang Undang R.I., No.28 Tahun 2014, Hak Cipta, L.N.R.I Tahun 2014 No. 266, Pasal 8.
} 
seluruh maupun sebagian karena: pewarisan; hibah; wakaf; wasiat; perjanjian tertulis; atau sebab lain yang dibenarkan sesuai dengan ketentuan peraturan perundang-undangan. Selain itu, hak cipta dapat dijadikan sebagai obyek jaminan fidusia. Hal ini dikarenakan hak cipta termasuk ke dalam benda bergerak yang tidak berwujud. Hak ekonomi yang dialihkan pencipta atau pemegang hak cipta untuk seluruh atau sebagian tidak dapat dialihkan untuk kedua kalinya oleh pencipta atau pemegang hak cipta yang sama.

\section{Pelaksanaan Hak Cipta Sebagai Jaminan Fidusia}

Jaminan fidusia telah dikenal dan digunakan di Indonesia sejak jaman penjajahan Belanda sebagai bentuk jaminan yang lahir dari yurisprudensi, yang berasal dari jaman Romawi. Bentuk jaminan ini biasanya digunakan secara luas dalam transaksi pinjam meminjam. Hal ini sebagai akibat bentuk jaminan ini dianggap lebih sederhana dan mudah dalam melakukan perkreditan.

Di Indonesia, pengaturan jaminan fidusia diatur di dalam Undang-Undang Nomor 42 Tahun 1999 Tentang Jaminan Fidusia. Fidusia yang berarti penyerahan hak milik atas dasar kepercayaan memberikan kedudukan kepada debitur untuk tetap menguasai barang jaminan, walaupun hanya sebagai peminjam pakai untuk sementara waktu atau tidak lagi sebagai pemilik. Lahirnya jaminan fidusia ini berawal dari adanya suatu perjanjian utang piutang. Hal ini berarti perjanjian fidusia ini merupakan perjanjian accessoir yang berarti bahwa lahir dan hapusnya perjanjian jaminan fidusia bergantung pada perjanjian pokoknya, yaitu perjanjian utang piutang. Dalam Pasal 4 Undang-Undang Jaminan Fidusia dinyatakan secara tegas bahwa jaminan fidusia merupakan perjanjian ikutan dari suatu perjanjian pokok yang menimbulkan kewajiban bagi para pihak untuk memenuhi suatu prestasi.

Konsep dasar dari jaminan fidusia berbeda halnya dengan gadai, hipotek, dan hak tanggungan. Perbedaan dari jaminan lainnya terlihat pada obyek dan penguasaan kebendaan. Dalam fidusia, obyek jaminan tidak dikuasai oleh pemberi hutang (kreditur) melainkan tetap dikuasai oleh penghutang (debitur), dan tidak 
ada penyerahan fisik. Hal ini berbeda halnya dengan gadai dan hipotek, benda yang dijaminkan dengan gadai dan hipotek, penguasaannya berada di tangan kreditur. Jaminan fidusia ini memberikan kepercayaan kepada debitur untuk memakai dan menggunakan obyek jaminan fidusia dalam menjalankan kegiatan usahanya. Asas kepercayaan ini digunakan pula pada jaminan hak tanggungan. Perbedaan hak tanggungan dan fidusia hanya berada pada obyek jaminan.

Perjanjian fidusia dibuat dengan akta otentik. Akta otentik adalah akta yang dibuat oleh atau di depan pejabat yang ditunjuk oleh undang-undang dan memiliki kekuatan pembuktian sempurna. Untuk akta yang dilakukan di bawah tangan biasanya harus diotentikkan ulang oleh para pihak jika hendak dijadikan alat bukti sah, misalnya di pengadilan. Jaminan Fidusia akan menjadi sempurna apabila perjanjian fidusia ini dilakukan pendaftaran. Apabila Jaminan Fidusia tidak dibuatkan dengan akta notarial dan tidak didaftarkan maka jaminan tersebut tidak mempunyai/tidak dapat dijerat dengan Undang-Undang Jaminan Fidusia, sehingga tidak memiliki nilai pembuktian sempurna.

Obyek jaminan fidusia adalah benda yang berwujud maupun tidak berwujud, yang terdaftar maupun tidak terdaftar, yang bergerak maupun yang tidak bergerak yang tidak dapat dibebani hak tanggungan atau hipotik. Pada umumnya, benda yang dijadikan obyek jaminan fidusia adalah benda yang bergerak yang berwujud, hal ini dikarenakan benda tersebut memiliki nilai yang nyata dan jelas di pasaran. Berbeda halnya dengan benda yang bergerak dan berwujud seperti halnya hak kekayaan intelektual, sulit untuk memberikan nilai pada jaminan fidusia.

Jelas disebutkan bahwa pada Undang-Undang Jaminan Fidusia, benda yang bergerak dan benda yang berwujud, seperti HKI dapat dijadikan sebagai obyek jaminan. Pada prakteknya, seringkali pemegang HKI dapat menjaminkan HKI nya tersebut sebagai jaminan untuk melunasi hutangnya. Akan tetapi, dalam peraturan mengenai HKI tidak dimuat mengenai pengaturan yang memperbolehkan HKI sebagai jaminan fidusia. Misalnya dalam Undang-Undang 
Nomor 19 Tahun 2002 Tentang Hak Cipta, tidak ada satu pasalpun yang menyebutkan hak cipta dapat dijadikan obyek jaminan fidusia. Hal ini mengakibatkan tidak adanya landasan hukum yang jelas apabila dalam prakteknya hak cipta dijadikan jaminan fidusia.

Dalam memenuhi kebutuhan masyarakat akan adanya kepastian hukum, pemerintah membentuk dan mengeluarkan undang-undang terbaru mengenai hak cipta, yaitu Undang-Undang Nomor 28 Tahun 2014 Tentang Hak Cipta. Alasan dibentuknya Undang-Undang Hak Cipta yang terbaru ini dikarenakan adanya kebutuhan cukup mendesak yang berhubungan dengan terus berkembangnya teknologi informasi dan komunikasi di mana dapat memiliki peran strategis dalam pengembangan Hak Cipta. Pengaturan yang baik akan tuntutan perkembangan teknologi, informasi, dan komunikasi, maka sendi-sendi kehidupan dan perekonomian Indonesia akan meningkat, dan kredibilitas citra bangsa yang baik akan tetap terjaga di dunia internasional.

Perbaharuan Undang-Undang Hak Cipta yang baru ini tentunya memiliki kelebihan sesuai dengan perkembangan tersebut, yaitu diawali dengan mengenai pengaturan perpanjangan jangka waktu perlindungan hak cipta. Diatur ulangnya mengenai jangka waktu perlindungan hak cipta dengan waktu lebih panjang, di mana pada undang undang lama pencipta dilindungi seumur hidup dan 50 tahun sesudah pencipta meninggal dan diperbaharui menjadi baru sampai dengan 70 tahun dan jangka waktu 70 tahun ini mengikuti sejumlah negara maju. Selanjutnya pengaturan mengenai sold flat, dalam undang-undang lama hanya dibahas pada bagian umum penjelasan tetapi di undang-undang terbaru ini dijelaskan lebih jelas mengenai sold flat, di mana bahwa hak ekonomi merupakan hak eksklusif pencipta maupun pemegang hak cipta untuk mendapatkan manfaat ekonomi atas ciptaan.

Pengaturan lainnya yang diubah dalam Undang-Undang Hak Cipta terbaru ini, lebih menegaskan mengenai penerapan delik aduan untuk tuntutan pidana dan pertanggungjawaban pihak pengelola apabila terjadi pelanggaran. Selain itu 
mengenai kewenangan menteri untuk menghapus ciptaan yang telah dicatat, penghapusan ini dilakukan apabila ciptaan tersebut melanggar norma agama, norma susila, ketertiban umum, pertahanan dan keamanan negara, serta ketentuan peraturan perundang-undangan. Dalam Undang-Undang Hak Cipta yang baru ini juga diatur bahwa pencipta, pemegang hak cipta, pemilik hak terkait, menjadi anggota Lembaga Manajemen Kolektif agar dapat menarik imbalan atau royalti dan Lembaga Manajemen Kolektif yang berfungsi menghimpun dan mengelola hak ekonomi pencipta dan pemilik hak terkait wajib mengajukan permohonan izin operasional kepada menteri. Undang-undang inipun memperbaharui penggunaan hak cipta dan hak terkait dalam sarana multimedia untuk merespon perkembangan teknologi informasi dan komunikasi.

Dalam Undang-Undang Hak Cipta yang terbaru ini dibahas mengenai benda bergerak tidak berwujud yang dapat dijadikan obyek jaminan fidusia. Hal ini terdapat pada Pasal 16 ayat 3 Undang-Undang Nomor 28 Tahun 2014 Tentang Hak Cipta yang menyebutkan secara jelas bahwa "Hak Cipta dapat dijadikan obyek jaminan fidusia". Pada ayat berikutnya dijelaskan, bahwa jaminan obyek fidusia dilaksanakan sesuai dengan ketentuan peraturan perundang-undangan. Peraturan ini tentunya memberikan suatu kepastian hukum bagi para pemegang hak cipta untuk menjaminkan ciptaannya. Dengan adanya peraturan ini terjadinya sinkronisasi antara Undang-Undang Jaminan Fidusia dan Undang-Undang Hak Cipta.

Menurut Undang-Undang Nomor 28 Tahun 2014 Tentang Hak Cipta, pelaksanaan dari pemberian hak cipta untuk dijadikan obyek jaminan fidusia mengacu pada ketentuan peraturan perundang-undangan. Peraturan perundangundangan yang dimaksud tidak jelas karena pada penjelasan undang-undang inipun tidak disebutkan secara jelas peraturan perundang-undangan yang manakah yang dipakai untuk melaksanakan penjaminan hak cipta sebagai jaminan fidusia. Dalam hal penjaminan hak cipta sebagai jaminan fidusia, tentunya berkaitan erat dengan Undang-Undang Jaminan Fidusia. Secara penafsiran 
sistematis, pelaksanaan penjaminan hak cipta akan sesuai dan mengacu kembali kepada Undang-Undang Jaminan Fidusia. Syarat dan ketentuan suatu benda dapat dijadikan obyek jaminan fidusia dan sahnya benda tersebut sebagai obyek jaminan fidusia harus sesuai dengan Undang-Undang Jaminan Fidusia.

Undang-Undang Fidusia mengharuskan agar setiap benda yang akan dijadikan jaminan fidusia harus didaftarkan ke Kantor Pendaftaran Fidusia. Apabila suatu hak cipta akan dijadikan sebagai jaminan fidusia, maka suatu ciptaan itu harus sudah didaftarkan terlebih dahulu di Direktorat Jendral Kekayaan Intelektual, selanjutnya hak cipta yang dijadikan obyek jaminan tersebut harus tetap didaftarkan ke Kantor Pendaftaran Fidusia. Pendaftaran melalui Kantor Jaminan Fidusia berguna agar hak cipta yang dijaminkan tersebut terdaftar dan pemegang fidusia mempunyai hak yang didahulukan. Selain itu, pendaftaran inipun penting sebagai bukti apabila terjadi wanprestasi, bahwa pemberi fidusia adalah pemegang hak cipta dan pelaksanaan eksekusi terhadap nilai ekonomi hak cipta dan pelaksanaan eksekusi terhadap nilai ekonomi hak cipta dapat dilakukan melalui lembaga parate executie.

Hak cipta dapat dijadikan sebagai salah satu obyek dari jaminan fidusia. Hal ini dikarenakan hak cipta mempunyai hak ekslusif yang dimiliki pemegang hak cipta/pencipta yaitu hak ekonomi. Hak ekonomi dari sebuah ciptaan berarti ciptaan tersebut mempunyai nilai ekonomi. Nilai ekonomi tersebut didapat oleh pencipta atau pemegang hak cipta terdapat dari pemanfaatan hak ekonomi atas obyek ciptaannya. Pemanfaatan hak ekonomi tersebut misalnya mendapatkan imbalan atas pemanfaatan obyek ciptaannya tersebut atau mendapatkan royalti apabila terjadi kontrak/perjanjian lisensi. Oleh karena itu, pihak yang berhak untuk menjaminkan hak ciptaannya adalah pencipta atau pemegang hak cipta.

Benda yang dapat dijadikan jaminan fidusia, tentunya harus memiliki nilai yang dapat diukur sebagai jaminan atas pelunasan hutang debitur. Dalam hal, hak cipta sebagai obyek jaminan fidusia sulit untuk mengukur nilai dari hak tersebut, karena yang dijaminkan adalah hak intelektual dari ciptaan. Hal ini menyebabkan 
diperlukan pihak ketiga sebagai lembaga appraisal penjaminan yang tepat bagi hak cipta untuk menjadi jaminan. Lembaga Manajemen Kolektif (LMK) sebagai salah satu lembaga yang dapat memberikan appraisal/penilaian terhadap nilai ekonomi dari hak cipta. Beberapa LMK yang ada di Indonesia adalah Karya Cipta Indonesia (KCI), Royalti Anugerah Indonesia (RAI), dan Wahana Musik Indonesia (WAMI). Para LMK inilah yang bertugas untuk mengumpulkan royalti dari para pengguna karya cipta dari para musisi ataupun penyanyi yang tergabung di masing-masing LMK. Pengguna karya cipta dapat beragam, seperti dari TV, karaoke, mall, kafe, ataupun restoran. LMK dapat menjadi acuan penyedia data untuk lembaga appraisal pada royalty performing rights pencipta/pemegang hak ciptanya.

Salah satu cara menghitung nilai ekonomi suatu hak cipta, misalnya lagu dapat dilihat dari seberapa seringnya lagu ciptaan tersebut diputar atau dimainkan (performing rights), sehingga pencipta lagu atau pemegang hak cipta mendapatkan imbalan ataupun royalti apabila terjadi perjanjian lisensi. Pada saat ini, para LMK tersebut berjalan masing-masing dan memiliki standarnya sendiri. Hal tersebut menyebabkan persentase royalti yang diterima tidak seragam dan tidak ada transparansi atas pengelolaan royalti tersebut. Para LMK tersebut tidak ada yang mengaudit, sehingga diperlukan badan yang lebih tinggi dari para LMK. Oleh karena itu, dibentuklah Lembaga Manajemen Kolektif Nasional (LMKN).

LMKN ini dibentuk di bawah payung Direktorat Jenderal Hak Intelektual Kementerian Hukum dan Hak Asasi Manusia akan bertugas mengatur pendapatan para seniman yang karyanya digunakan secara komersial. Namun LMKN belum dapat bekerja secara maksimal. Masih banyak yang belum terancang dengan sempurna, masih dalam pembahasan, seperti royalti yang akan dikenakan untuk pencipta, penyanyi, produser, dan seluruh pihak yang terlibat dalam karya tersebut. LMKN dituntut untuk dapat menjamin kesejahteraan dari para musisi terkait royalti, namun tidak memberatkan para pengguna karya dari musisi- 
musisi berbakat Indonesia. Oleh karena itu, fungsi dari LMK dan kerjasama antara LMK dan LMKN harus berjalan dengan baik sebagai lembaga yang menarik dan mendistribusikan royalti. Selain itu, lembaga lain yang bisa memberikan data terhadap nilai ekonomi dari hak cipta adalah publishers, labels, media riset.

\section{Penutup}

Di dalam Undang-Undang Nomor 19 Tahun 2002 Tentang Hak Cipta tidak dimuat mengenai hak cipta sebagai obyek jaminan fidusia. Hal ini membuat disharmonisasi antara Undang-Undang Jaminan Fidusia dan Undang-Undang Hak Cipta. Selain itu, apabila dalam praktek terjadi penjaminan hak cipta sebagai jaminan fidusia, maka tidak ada landasan hukum yang jelas mengenai penjaminan hak cipta sebagai jaminan fidusia. Jaminan Fidusia semakin marak digunakan dalam hal perkreditan dan obyek yang menjadi jaminan semakin beragam, salah satunya adalah hak cipta.

Untuk memenuhi kebutuhan masyarakat, pemerintah memperbaharui dan membentuk Undang-Undang Hak Cipta yang terbaru, yaitu Undang-Undang Nomor 28 Tahun 2014 Tentang Hak Cipta. Dalam undang-undang ini secara jelas disebutkan bahwa hak cipta dapat dijadikan jaminan fidusia. Oleh karena itu, syarat sahnya hak cipta sebagai jaminan fidusia tetap berpatokan kepada UndangUndang Jaminan Fidusia.

Hak cipta sebagai hak intelektual yang memiliki hak eksklusif, yaitu hak moral dan hak ekonomi termasuk ke dalam jaminan kebendaaan. Sebagai jaminan kebendaan, hak cipta tentunya memerlukan appraisal/penilaian terhadap hak cipta tersebut. Dalam melakukan penilaian terhadap nilai ekonomis suatu hak cipta akan lebih sulit dibandingkan dengan untuk mengukur nilai ekonomi dari benda bergerak yang berwujud. Nilai ekonomi yang dapat dijaminkan adalah nilai dari pemanfaatan hak ekonomi dari barang/obyek ciptaannya tersebut. Pemanfaatan hak ekonomi tersebut dapat dilihat dari imbalan yang didapat atas pemanfaatan tersebut ataupun dari royalti. Untuk membantu menilai appraisal 
dari sebuat hak cipta, dibutuhkan LMK sebagai salah satu lembaga yang dapat memberikan penilaian terhadap nilai ekonomi dari hak cipta.

Pada Undang-Undang Hak Cipta Nomor 28 Tahun 2014 Tentang Hak Cipta sudah baik memuat mengenai ketentuan hak cipta dapat dijadikan obyek jaminan fidusia. Akan tetapi diperlukan peraturan yang lebih khusus seperti peraturan pelaksana dari undang-undang mengenai hak cipta yang dapat dijadikan fidusia. Peraturan pelaksana ini diperlukan untuk memperjelas pelaksanaan dari hak cipta sebagai jaminan fidusia, terutama untuk menilai appraisal dari sebuah hak cipta, sehingga mempunyai kepastian hukum yang jelas. Selain itu, lembaga keuangan bank ataupun non bank perlu diberikan penyuluhan hukum agar dapat memberikan pinjaman kredit dengan jaminan hak cipta, sehingga Undang-Undang Nomor 28 Tahun 2014 Tentang Hak Cipta dapat dilaksanakan dan berguna bagi masyarakat.

\section{Daftar Pustaka}

\section{Buku:}

Arif Lutfiansori, Hak Cipta dan Perlindungan Folklor di Indonesia, Graha Ilmu, Yogyakarta, 2010.

Direktorat Jendral Hak Kekayaan Intelektual Kementerian Hukum Dan Hak Asasi Manusia R.I., Buku Panduan Hak Kekayaan Intelektual, Tanggerang, 2013.

Rachmadi Usman, Hukum Hak Atas Kekayaan Intelektual: Perlindungan dan Dimensi Hukumnya di Indonesia, Alumni, Bandung, 2003.

Eddy Damian, Hak Kekayaan Intelektual: Suatu Pengantar, PT. Alumni, Bandung, 2006.

Kamus Besar Bahasa Indonesia, Alumni, Bandung, 1988.

M. Hutauruk, Peraturan Hak Cipta Nasional, Erlangga, Jakarta, 1982.

Muhamad Djumhana dan Djubaedillah, Hak Milik Intelektual Sejarah, Teori dan Prakteknya di Indonesia, Citra Aditya Bakti, Bandung, 1993.

Munir Fuadi, Jaminan Fidusia, PT. Citra Aditya Bakti, Bandung, 2000.

Munir Fuady, Hukum Jaminan Utang, Erlangga, Jakarta, 2013.

OK. Saidin, Aspek Hukum Hak Kekayaan Intelektual (Intellectual Property Rights), Rajawali Pers, Jakarta, 2010.

Sri Soedewi Mascjhun Sofwan, Beberapa Masalah Pelaksanaan Lembaga Jaminan Fidusia Di Dalam Praktik dan Perkembangan di Indonesia, Fakultas Hukum UGM, Yogyakarta, 1980.

Tan Kamello, Hukum Jaminan Fidusia, PT. Alumni, Bandung, 2014. 
Utomo Suryo Tomi, Hak Kekayaan Intelektual di Era Global, Graha Ilmu, Yogyakarta, 2010.

\section{Jurnal dan Makalah:}

Budi Agus Riswandi, Permasalahan Pelanggaran dan Langkah Hukum Hak Cipta Atas Musik dan Lagu yang Dituangkan Dalam Bentuk VCD dan DVD, Jurnal Hukum, Volume 16, Nomor 4, 573, 2009.

Jatmiko Winarno, Perlindungan Hukum Bagi Kreditur Pada Perjanjian Jaminan Fidusia, Jurnal Independent Fakultas Hukum, ISSN: 2338-7777.

Ketut Marita Widyasari Puspita, I Gusti Ayu Puspawati dan Marwanto, Pelaksanaan Pengikatan Jaminan Fidusia Dalam Kredit Perbankan, Jurnal Hukum Bisnis Fakultas Hukum Universitas Udayana, Volume 02, Nomor 01, 2, 2014.

Marulak Pardede, Implementasi Jaminan Fidusia Dalam Pemberian Kredit di Indonesia, Laporan Akhir Penelitian Hukum, Badan Pembinaan Hukum Nasional, Departemen Hukum dan HAM Republik Indonesia, Jakarta, 2006.

Sudjana, Hak Cipta sebagai Jaminan Kebendaan Bergerak dikaitkan dengan Pengembangan Obyek Fidusia, Jurnal Mimbar Hukum UGM, Volume 24, Nomor 3, 2012.

\section{Perundang-undangan:}

Undang-Undang Nomor 42 Tahun 1999 tentang Jaminan Fidusia.

Undang-Undang Nomor 28 Tahun 2014 tentang Hak Cipta.

\section{Internet:}

World Bank, Global Economic Prospects And The Developing Countries 129, http://siteresources.worldbank.org/INTGEP2002/Resources/gep2002co mplete.pdf

KemenkumHAM, Pembahasan RUU tentang Hak Cipta, http://www.djpp. kemenkumham.go.id/pembahasan-ruu/64-rancangan-UndangUndang/2112-rancangan-Undang-undang-tentang-hak-cipta.html.

Sosialisasi Undang-Undang No.28 Tahun 2014 tentang Hak Cipta di Kampus UGM, Undang-Undang Hak Cipta terbaru Terhadap Iklim Hukum Bisnis Di Indonesia, http://lppm.ugm.ac.id/2014/11/sosialisasi-uu-no-28-tahun2014-tentang-hak-cipta-di-kampus-ugm/ 